\title{
A new Argiloborus from Christmas Island, Australia (Coleoptera: Carabidae)
}

\author{
Pier Mauro Giachino \\ Settore Fitosanitario Regionale, Environment Park, Palazzina A2, via Livorno 60, 10144 Torino, Italy. \\ Email: PierMauro.Giachino@regione.piemonte.it
}

KEYWORDS: taxonomy, new species, Christmas Island, Argiloborus

urn:Isid:zoobank.org:pub:960C3C20-029D-4EA0-83D9-E377B5DC1647

\section{INTRODUCTION}

My colleague Martin Baehr of Munchen (Germany) kindly sent to me two specimens of a Carabidae Anillina received for study by the Western Australian Museum in Perth. These specimens, coming from Christmas Island in the Indian Ocean, belong to a new species of Argiloborus Jeannel, 1937, that is the object of this short note.

\section{MATERIAL AND METHODS}

The male specimen was previously included in Canada Balsam and used for the drawings. The drawings were made by means of a camera lucida connected to a Leica Biological Microscope DM2500 equipped with differential interference contrast.

The following acronyms have been used:

WAM: Western Australian Museum, Perth, Western Australia

Family Carabidae Latreille, 1802

Genus Argiloborus Jeannel, 1937

Argiloborus nativitatis sp. nov.

Figures 1, 2

urn:Isid:zoobank.org:act:C6E08C62-D059-4A4B-82C840C46C6FFF49

\section{MATERIAL EXAMINED}

\section{Holotype}

Australia: Christmas Island: ${ }^{\lambda}, 19^{\text {th }}$ Hole, cave CI-19, 10²5’30'S 105'42'04'’E, 30 April 2006, J. Anderson (BES: 13583) (WAM E89194).

\section{Paratype}

Australia: Christmas Island: 1 q, collected with holotype (WAM E89195).

\section{DIAGNOSIS}

An Argiloborus belonging to a distinct species group, not strictly related to other known species of the Oriental region (Giachino 2001; 2003), (probably due to a still fragmentary knowledge). A. nativitatis n. sp. is characterized by the followings characters: pronotum having lateral sides without denticulation in front of the basal angles; labial tooth absent; $8^{\text {th }}$ pore of the umbilicate series placed posteriorly to the $9^{\text {th }}$; posterior discal seta absent; elytral pubescence very short; two dilated protarsomeres, without adhesive phanerae, in males; parameres without apical setae.

\section{DESCRIPTION}

A very small species with total length $0.89-0.90 \mathrm{~mm}$ (from anterior margin of labrum to apex of elytra). Body elongated, relatively slender, depigmented testaceous, with legs, antennae, and palpi slightly paler; integuments shiny, with a distinct microsculpture, covered with a very sparse and short pubescence.

Head: quite anophthalmous, large, but slightly narrower than pronotum. Labium without tooth. Antennae robust, moniliform, very short, not reaching base of pronotum when stretched backwards. Clypeofrontal groove distinct; anterior margin of epistome subrectilinear.

Pronotum: slightly transverse (max width/max length ratio $=1.17 \delta^{\lambda}$ ), with maximum width at about base of anterior fourth, narrowed basally, where it is clearly narrower than anterior margin; sides poorly and not regularly arcuate anteriorly, subrectilinear posteriorly, distinctly sinuate just before base and not denticulate. Fore angles broadly obtuse and slightly rounded, not prominent; posterior ones right but not pointed apically. Base slightly sinuate. Disc barely convex, with very short and sparse pubescence; median groove very shallow, scarcely marked. Marginal groove wide and flattened, enlarged near base; anterior marginal setae inserted inside marginal groove, almost at anterior fifth; basal setae placed at posterior angles. 
Legs: robust, with protarsi pentamerous, two basal protarsomeres slightly dilated and without adhesive phanerae in male.

Elytra: subrectangular, elongated (max length/ max width ratio $=1.70 \quad \delta^{\pi}$ ), with maximum width at midlength, not emarginated at pre-apical area. Disc moderately convex; integuments shiny, with an evident microsculpture and very short, sparse and upright pubescence. Humeri well marked, rounded, posthumeral margin denticulate, with an evident crenellation, distinct up to apical fourth and bearing setae; elytral apices separately rounded. Marginal groove wide and evident up to $7^{\text {th }}$ pore of umbilicate series.

Chaetotaxy: basal umbilicate pore large, foveate. Umbilicate series of type B (sensu Jeannel 1963), first three pores of humeral group almost equidistant $\left(1^{\text {st }}\right.$ and $2^{\text {nd }}$ ones very slightly closer to each other), $4^{\text {th }}$ pore decidedly farther and inserted posteriorly to base of anterior third of elytron; $5^{\text {th }}$ placed almost at base of posterior third of elytron; $5^{\text {th }}$ and $6^{\text {th }}$ about half as distant from each other than distance between $6^{\text {th }}$ and $7^{\text {th }} ; 8^{\text {th }}$ slightly displaced onto disc and after $9^{\text {th }} ; 7^{\text {th }}, 8^{\text {th }}$ and $9^{\text {th }}$ not equidistant, with $9^{\text {th }}$ and $8^{\text {th }}$ very close to each other. Discal setae absent.

Aedeagus (Figure 2): small, with basal bulb small; median lobe, in lateral view, short, stumpy, and showing a swollen aspect, with ventral margin irregularly curved; apical blade short, subtriangular. Inner sac bearing two phanerae: first one dorsal, large and tubular, second one placed in ventral-median area, like a flagellum. Parameres stocky and relatively short, exceeding in length half of median lobe; without apical setae.

\section{ETYMOLOGY}

The species name refers to Christmas, the Nativity.

\section{DISTRIBUTION AND ECOLOGY}

A. nativitatis sp. nov. is presently known only from its type locality. The biology of this species is unknown.

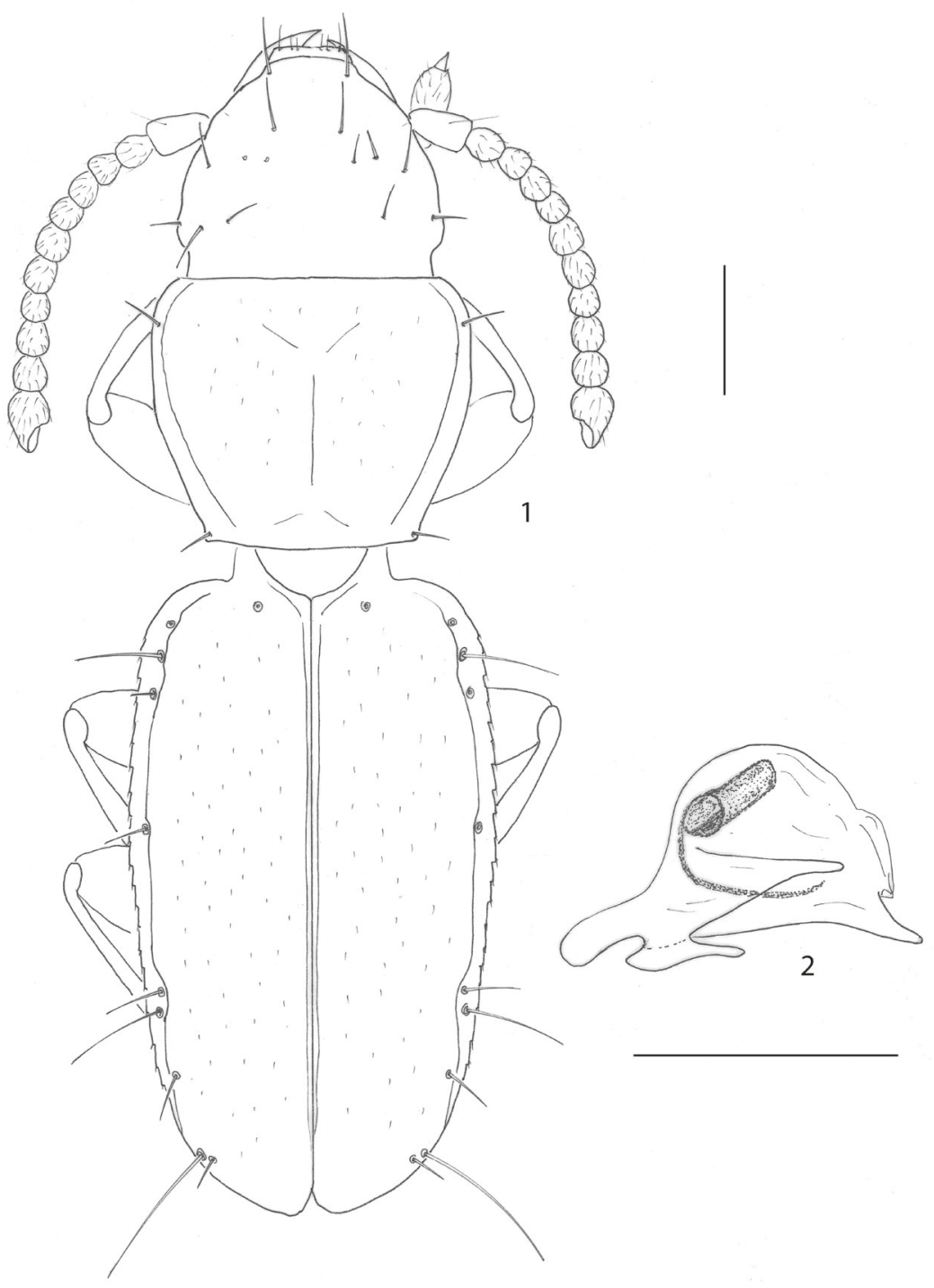

FIGURES 1-2 Argiloborus nativitatis sp. nov., holotype ô. 1: habitus; 2: aedeagus in lateral view. Scale bars : $0.1 \mathrm{~mm}$. 


\section{DISCUSSION}

After a first contribution by Humphreys and Eberhard (2001), a review of the subterranean fauna of Christmas Island, with emphasis on aquatic fauna, was recently published by Humphreys (2014). He pointed out that Christmas Island is the emergent part of an isolated seamount that rises $4.5 \mathrm{~km}$ from the ocean floor. The island, that reaches an altitude of $361 \mathrm{~m}$ asl, is a carbonate cover island (sensu Mylroie et al. 2001; Jensen et al. 2002) in which the volcanic basalt core (from Cretaceous to Early Tertiary) was encased in more recent carbonate rocks. Christmas Island was subjected to both tectonic uplift and eustatic changes that resulted in major sea level changes relative to the island (Humphrey 2014). Grimes (2001) stated that deposition of the main limestones on Christmas Island ceased during the mid-Miocene (10 Ma) when the limestone would have been emergent and exposed to karstification.

Specialized subterranean terrestrial fauna is conspicuously less numerous than subterranean aquatic fauna (Humphrey 2014). The only subterranean ground beetle actually known is Lymnastis brooksi Baehr, 2008, recently described from Jane Up Cave. Argiloborus nativitatis sp. nov., second blind Carabid beetle known for this island, regardless to having been found in a cave, appears to be an endogean species, rather than a true hypogean beetle (sensu Giachino and Vailati 2010; 2016). Its morphological features suggest an edaphic life style rather than in caves or in bedrock fissures (Giachino and Vailati 2010).

\section{ACKNOWLEDGEMENTS}

I am greatly indebted to Martin Baehr (München, Germany) who sent for study this interesting new species. A special thanks to my friends Achille Casale for useful suggestions and improvements to the early version of the manuscript and Massimo Meregalli for suggestions on the first English version.

\section{REFERENCES}

Giachino, P. M. (2001). New data on the Anillina (Coleoptera, Carabidae: Bembidiini) of the Oriental Region. Spixiana 24(3): 203-206.

Giachino, P. M. (2003). New Anillina (Coleoptera, Carabidae: Bembidiini) of the Oriental Region. In: Cuccodoro, G. and Leschen, R. (eds). Systematics of Coleoptera: papers celebrating the retirement of Ivan Löbl. Memoirs on Entomology International 17: 21-51.

Giachino, P. M. and Vailati, D. (2010). The subterranean environment. Hypogean life, concepts and collecting techniques. WBA Handbooks 3. 130 pp.

Giachino, P. M. and Vailati, D. (2016). Riflessioni sulla terminologia biospeleologica: i concetti di troglobio, troglofilo e troglosseno. Atti del Convegno Nazionale 'La ricerca carsologica in Italia', 22-23 giugno 2013, Laboratorio carsologico sotterraneo di Bossea, Frabosa Soprana (June 1): 195-200.

Grimes, K. (2001). Karst features on Christmas Island (Indian Ocean). Helictite 37(2): 41-58.

Humphreys, W. F. (2014). Subterranean fauna of Christmas Island: habitats and salient features. Raffles Bulletin of Zoology 30: 29-44.

Humphreys, W.F. and Eberhard, S.M. (2001). Subterranean fauna of Christmas Island, Indian Ocean. Helictite 37(2): $59-74$.

Jensen, J.W., Mylroie, J.E., Mylroie, J.R. and Wexel, C. (2002). Revisiting the carbonate island karst model. Geological Society of America, Abstracts with Programme 34: 226.

Mylroie, J.E., Jensen, J.W., Taborosi, D., Jocson, J.M.U., Vann, D. and Wexel C. (2001). Karst features of Guam in terms of a general model of carbonate island karst. Journal of Cave and Karst Studies 63: 9-22.

MANUSCRIPT RECEIVED 8 SEPTEMBER 2016; ACCEPTED 7 OCTOBER 2016. 